\title{
"The effects of managerial ownership, leverage, dividend policy in minimizing agency problem"
}

\begin{tabular}{|c|c|}
\hline AUTHORS & $\begin{array}{l}\text { Alni Rahmawati (D https://orcid.org/0000-0003-0618-224X } \\
\text { M. Moeljadi (Dttps://orcid.org/0000-0002-9232-922X } \\
\text { Djumahir (D https://orcid.org/0000-0002-0935-8389 } \\
\text { Sumiati }\end{array}$ \\
\hline ARTICLE INFO & $\begin{array}{l}\text { Alni Rahmawati, M. Moeljadi, Djumahir and Sumiati (2018). The effects of } \\
\text { managerial ownership, leverage, dividend policy in minimizing agency problem. } \\
\text { Investment Management and Financial Innovations, 15(4), 273-282. } \\
\text { doi:10.21511/imfi.15(4).2018.22 }\end{array}$ \\
\hline DOI & http://dx.doi.org/10.21511/imfi.15(4).2018.22 \\
\hline RELEASED ON & Thursday, 06 December 2018 \\
\hline RECEIVED ON & Friday, 05 October 2018 \\
\hline ACCEPTED ON & Tuesday, 20 November 2018 \\
\hline LICENSE & $\begin{array}{l}(\mathrm{coc}) \mathrm{EY} \\
\text { This work is licensed under a Creative Commons Attribution } 4.0 \text { International } \\
\text { License }\end{array}$ \\
\hline JOURNAL & "Investment Management and Financial Innovations" \\
\hline ISSN PRINT & $1810-4967$ \\
\hline ISSN ONLINE & $1812-9358$ \\
\hline PUBLISHER & LLC "Consulting Publishing Company "Business Perspectives" \\
\hline FOUNDER & LLC "Consulting Publishing Company "Business Perspectives" \\
\hline
\end{tabular}

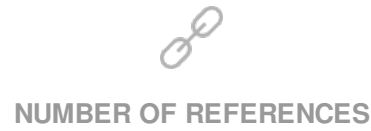

41

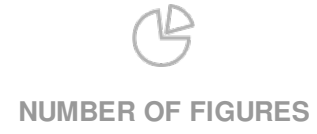

0

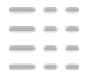

NUMBER OF TABLES

3

(C) The author(s) 2021. This publication is an open access article. 


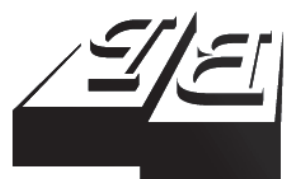

BUSINESS PERSPECTIVES

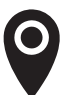

LLC "CPC "Business Perspectives" Hryhorii Skovoroda lane, 10, Sumy, 40022, Ukraine

www.businessperspectives.org

Received on: $5^{\text {th }}$ of October, 2018 Accepted on: $20^{\text {th }}$ of November, 2018

(C) Alni Rahmawati, Moeljadi, Djumahir, Sumiati, 2018

Alni Rahmawati, Doctoral Student, Faculty of Economics and Business, University of Brawijaya, Indonesia.

Moeljadi, Prof., Lecturer, Faculty of Economics and Business, University of Brawijaya, Indonesia.

Djumahir, Dr., Lecturer, Faculty of Economics and Business, University of Brawijaya, Indonesia.

Sumiati, Dr., Lecturer, Faculty of Economics and Business, University of Brawijaya, Indonesia.

Alni Rahmawati (Indonesia), Moeljadi (Indonesia), Djumahir (Indonesia),

Sumiati (Indonesia)

\section{THE EFFECTS OF MANAGERIAL OWNERSHIP, LEVERAGE, DIVIDEND POLICY IN MINIMIZING AGENCY PROBLEM}

\section{Abstract}

The research intends to minimize agency conflict through causality effects of managerial ownership, leverage, and dividend policy, where agency conflict is still interesting issue to discuss, as it concerns the principals' and agents' interests. The research covers 33 go-public manufacturers in Indonesia Stock Exchange. It involves 198 samples in the period 2010-2015. It applies saturation sampling and balanced panel data. For analysis model, it applies Granger bidirectional/simultaneity analysis, with variables of managerial ownership, leverage and dividend policy. The research shows that: 1) there is no bidirectional causality between managerial ownership and leverage (5\%);2) there is no bidirectional causality between managerial ownership and dividend policy $(5 \%) ; 3)$ there is no bidirectional causality between leverage and dividend policy (10\%).

Keywords

JEL Classification

\section{INTRODUCTION}

Corporations in Indonesia have unique position (except state-owned corporations), $99 \%$ of limited liability corporations in Indonesia come from family corporations evolving into limited liability status. Though they are in limited status, characteristics of family business still dominate and corporation managements are commonly on the hand of family members. At this point, agency problem and asymmetric information are non-existent. However, these issues are found in stateowned corporations with limited liability status (including those that have been go-public), as they make separation between shareholders and management. This makes limited liability status an interesting object to discuss both in terms of corporate law and corporate finance, and the existence of agency problem, that is, conflictual clash.

According to Jensen et al. (1976), Jensen (1986), Weston and Brigham (1994), agency problem could raise in two forms of relationships, that is: 1) that between principal and agent; and 2) that between principal and creditor. Djebali et al. (2012) say that agency problem is one of interesting issues, much discussed and debated till today in finance literature, especially it concerns the relationship between principal and agent.

Agency problem could arise, because agent and principal have different purposes. The premise of theory is that agent tends to be self-interested, risk averse, and rational actor with less effort (moral hazard) and ad- 
verse selection (Jensen et al., 1976). According to Eisenhardt (1989), agency problem relates to: 1) monitoring problem as principal cannot prove if agent has behaved in the right way; 2) risk sharing problem, especially in outcome control case, which rises when principal and agent have different attitude to risk.

According to Frankfurter et al. (2002), Al-Malkawi (2007), and Al-Taleb (2012), agency conflict could be mitigated or minimized, and the ways to minimize have been widely explored in modern finance literature, especially in their relation to capital structure/leverage, dividend policy known as dividend puzzle, and ownership structure. Modigliani and Miller (1963) hold that leverage maximization can be linked to agency problem, where leverage might serve as disciplinary mechanism that can mitigate agency problem by stock take-over. Al-Taleb (2012) argues that the increase of dividend share can curb agency problem. Rozeff (1982) in Mursalim (2009) also argues that dividend payment is one of the available ways to mitigate agency problem. Liao and Chien (2013) argue that increased managerial ownership would make managers' and shareholders' interests converge, and it would enhance corporation's value, and decrease agency problem.

Several researchers have shown that 1) ownership structure (Jensen et al., 1976; Bathala et al., 1994; Moeljadi, 2006; Djebali et al., 2012), 2) capital structure (Modigliani \& Miller, 1958, 1963; Djebali, et al., 2012). 3) dividend policy (Frankfurter et al., 2002; Al-Malkawi, 2007; Al-Taleb, 2012) are still very interesting issues to discuss/debate to developing agency theory. According to McCraw (1990) in Liao and Chien (2013), Jensen and Ruback (1983), Sundaramurthy (2005), the above issues might develop agency theory, and hold that ownership structure, leverage and dividend can mitigate agency cost.

Jensen et al. (1992), Chen and Steiner (1999), Crutchley et al. (1999), Nyonna (2012), Vo and Nguyen (2014) state that agency cost arising from agency problem between principal and agent can be minimized by bidirectional causality between leverage, ownership structure and dividend policy (debt policy). Jensen et al. (1992) hold that bidirectional causality analysis provides a better and clearer description than unidirectional causality, and it lends support from Chow and Rice (1982), Tsay et al. (2008) arguing that simultaneity analysis can explore relationship between variables more accurately and produce higher estimation efficiency.

Existing research provides mixed results regarding bidirectional causality between managerial ownership, leverage, and dividend policy. Eisenhardt (1989) and Bathala et al. (1994) examine different variables to prove their mitigating effect on agency conflict. It holds true to other works such as Liao and Chien (2013), Jensen and Ruback (1983), Sundaramurthy (2005), Alderson et al. (2013).

The research intends to minimize agency problem in agency theory by applying managerial ownership, leverage, dividend policy by means of bidirectional causality testing.

\section{LITERATURE REVIEW}

\subsection{Agency theory}

Agency theory has held a central position in a corporate governance literature and is a basis to understand corporate governance. The theory concerns the contractual relationship between members in a corporation. Jensen et al. (1976) clarify that agency relationship holds when an individual or two (principal) employ another individual (agent) for his or her service and del- egate authority to him or her to make decision. Principal is shareholder or investor, while agent is management who runs corporation. The point of agency is division of functions between ownership by shareholders and control by management. According to Eisenhardt (1989), agency theory is made of three assumptions, that is, those of human nature, organization, and information.

Jensen et al. (1976) hold that corporations are built within modern principles, subject to agency con- 
flict issue, derived from separation between corporate ownership and corporate management. Controlling right given to managers is subject to abuse and might slip into agency issue, where investors have low trust that money they invest would be well managed by managers.

Vo and Nguyen (2014) hold that the role of managers is to maximize the fortune of shareholders. However, managers do not hold significant shares, thus their decisions tend not to be affected by shareholders' interests.

\subsection{Managerial ownership}

Managerial ownership refers to share percentage owned by corporate managers and directors at the year-end. Technical issue would not come to the fore if corporate ownership and management are not performed separately. Owners (principals) focus on maximizing fortune by looking at present value of cash flow energized by corporate investment, while managers focus on the increase of corporate growth and size.

Corporate ownership by managers can be seen as bridging the interest difference between shareholders and managers. Thus, agency issue could be omitted if managers are also shareholders. According to Jensen et al. (1976), managerial share ownership might help align interests between shareholders and managers. The change in ownership structure is expected to lead to profitmaximization oriented corporate governance and decision-making.

\subsection{Capital structure/leverage}

Kraus and Litzenberger (1973) hold that maximizing debt value serves as a solution when it comes to tax and financial distress, but this condition cannot predict leverage in capital structure, because it ignores some factors that determine debt policy, especially agency, which is contradictory in corporate finance decision. Jensen et al. (1976) have analyzed the effect of agency conflict in corporation by relating to debt policy. Theories related to capital structure are pecking order theory and trade-off theory.
Pecking order is a theory of financing decision where managers put priority to retained earning, debt and stock issuance to use first as financing resources because of their lower risks (Hanafi \& Mahmud, 2004). Pecking order theory emphasizes information asymmetry. This asymmetry affects corporate capital structure by limiting access to external financing sources.

Trade-off theory explains optimum capital structure, that is, balance between the costs of financial distress, agency problem and benefit of leverage (tax shield). According to this trade-off theory, leverage level is affected by corporate growth level. Corporation with high growth tends to finance its investment by issuing stocks because of its relatively high price.

\subsection{Dividend policy}

Kieso et al. (2015) state that dividend policy is a decision to share profits with corporate owners. The policy intends to make alignment between managers and shareholders. Dividends shared could be cash dividend or stock dividend. There are three schools of dividend policy. The first school (Gordon \& Gordont, 1963) supports the idea of paying very high dividends, based on the fact that shareholders prefer secure position, tend to be risk averse. All profits should be paid as dividends, so the dividends would worth two or three times the respective corporations' stock value. Second school (Miller \& Modigliani, 1961) supports the idea that dividend policy is not relevant, as it does not have an effect on return rate. This theory is considered by Gordon and Gordont (1963) as bird in the hand theory. Gordon (1959) assumes that investor sees that one bird in the hand is more valuable than thousand birds in the sky. Dividend has a higher certainty than capital gain. Third school (Brennan, 1970) supports the idea that investors prefer to have lower dividends, as they are imposed with higher taxes than capital gain based on the context of US in 1986. Another popular perspective regarding dividend relevance is put forward by Jensen et al. (1976) and extended by Rozeff (1982) with agency theory. It is derived from conflictual interests between manager (agent) and shareholder (principal). 


\section{HYPOTHESES}

\subsection{Bidirectional causality between managerial ownership and dividend payout ratio to minimize agency problem}

Based on Miguel and Brito (2011), the relationship between managerial ownership and dividend payout ratio could be improved by means of constitutive or complementary relationship, which is directed at reducing agency costs, it becomes more effective to use two variables to influence each other at the same time to solve the same problem.

Rozeff (1982) argues that high managerial ownership reduces the number of dividends paid to shareholders. It in turn decreases return paid in the form of dividend. Thanatawee (2013) shows that the size of dividend payout ratio is affected by the increase (decrease) in managerial stock ownership. Dividend payments can be a substitute mechanism in reducing cash flows that may be misused by managers. This shows that increasing dividend payments will also cause a decrease in managerial ownership.

Vo and Nguyen (2014) hold that in terms of substitution, managerial ownership has negative relationship with dividend payout ratio applied to control/decrease agency cost. Rozeff (1982) argues that dividend policy and managerial ownership are "subtitute tools" applicable to reduce agency cost.

Managerial ownership and dividend can be considered as substitutive mechanism that make them interchangeable and managed to mitigate agency conflict. Lower dividend would increase possibility for managerial ownership and otherwise.

H1: There is a significant and negative bidirectional effect of managerial ownership on dividend payout ratio in minimizing agency problem.

\subsection{Bidirectional causality between managerial ownership and leverage to minimize agency problem}

Nyonna (2012), Jensen et al. (1992), Bathala et al. (1994), Vo and Nguyen (2014) show that in a substitutive manner, managerial ownership has a significant negative effect on leverage (debt), and this would decrease agency conflict, especially agency cost.

The high managerial ownership increases managers' opportunistic behaviors that might upset share holders. Debt might serve as a solution for this problem. It might increase monitoring from bondholders and makes shareholders more reassured as investment financing does use their money so it decreases risk from shareholders.

H2: There is a significant negative bidirectional effect of managerial ownership on leverage in minimizing agency problem.

\subsection{Bidirectional causality between dividend payout ratio and leverage to minimize agency problem}

Vo and Nguyen ( 2014) find that in a substitutive manner, dividend payout ratio has a negative effect on leverage (debt) so that it can be used to control/decrease agency cost. Increasing dividend payments for shareholders aims to increase investor confidence in the company and influence debt reduction, because companies tend to use internal funds that have a lower risk. Increasing the source of funds originating from debt will increase the risk borne by the company, thereby reducing dividend payments. This condition is also used to discipline managers.

In the agency conflict context, the negative effect means that the dividend payout mechanism can be used to substitute the influence of the debt that plays a role in controlling the agency conflict. This indicates that there is a reciprocal relationship between dividend policy and debt policy. 
H3: There is a significant negative bidirectional effect of dividend payout ratio on debt policy in minimizing agency problem.

\section{METHODS}

\subsection{Sampling and data sources}

The research population is go-public manufacturers listed in Indonesia Stock Exchange (BEI). It applies non-probability sampling with saturating (census) technique. The criteria are that a manufacturer has paid dividends in a row in the period 2010-2015. It applies secondary data with balanced panel data. The sample number is 198 (balanced panel data) with 33 corporations. It makes cross section and time series analysis from the data.

\subsection{Measurement of variables and research model}

Measurement of managerial ownership (MO) variable

Formula to determine managerial ownership based on Jensen (1986), Chen and Steiner (1999) is as follows:

$$
\text { Managerial ownership }=\frac{D \& C \operatorname{SHRS}_{i t}}{\operatorname{TOTSHRS}_{i t}},
$$

where $D \& C S H R S_{i t}$ - stock ownership (board of directors, board of commissioners) of corporation $i$ in year $t$, TOTSHRS $S_{i t}$ - total number of common stock of corporation in year $t$.

\section{Measurement of leverage (LEV) variable}

Formula to determine leverage based on Bhatala et al. (1994) is as follows:

$$
\text { Leverage }=\frac{\text { Total Debt }_{i t}}{\text { Total Equity }} .
$$

Measurement of dividend policy variable (DEV)

The formula sets the dividend payout ratio as follows (Rozeff, 1982; Anil \& Kapoor, 2008; Collins \& Kothari, 1989).
Divident Payout Ratio $=\frac{\text { Dividend per } \text { share }_{i t}}{\text { Profit per } \text { share }_{i t}}$

\subsection{Data analysis method}

For data analysis and inferences, it applies Granger causality test by means of program EViews 10 . Granger causality test is an analytical model clarifying the performed relationship between two variables and finding out if the relationship is single or bidirectional. Put in another way, it explores whether $X$ causes $Y$ or otherwise. To do so, there are several steps to take:

\subsection{Test for the best model}

Before performing Granger causality test, it is necessary to perform the test of choosing or determining the best model. To do so, it applies AIC coefficient (Akaike Info Criterion) and SIC (Schwarz Info Criterion). The best model has the lowest AIC or SIC value.

\subsection{Engle-Granger causality test}

The purpose of Granger causality test is to explore if A precedes B or otherwise, or whether the relationship between A and B is bidirectional.

\subsection{Research conceptual framework}

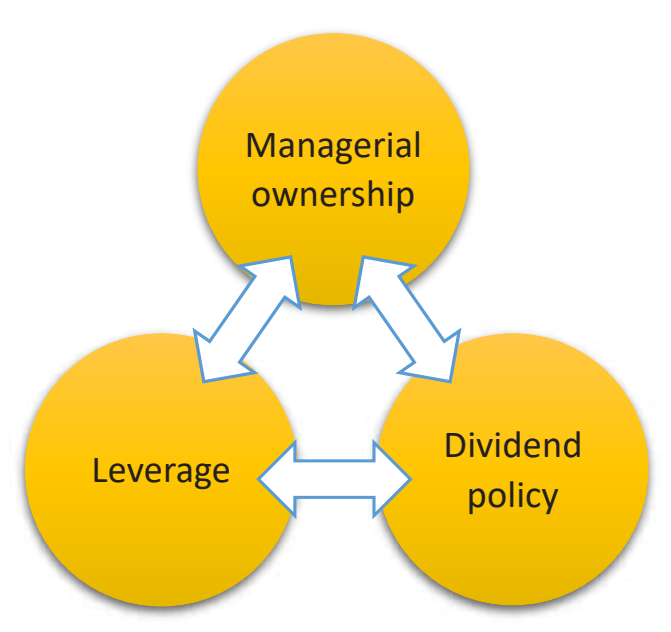

Figure 1. Research conceptual framework 


\section{RESEARCH RESULTS}

\subsection{Statistic descriptiption}

Table 1. Description of managerial ownership, leverage, dividend policy

Source: Data processing

\begin{tabular}{l|c:c:c}
\hline Information & MO & LEV & DIV \\
\hline Mean & 0.512116 & 0.851025 & 0.756076 \\
\hline Maximum & 0.987000 & 7.912000 & 5.525000 \\
\hdashline Minimum & 0.020000 & 0.103000 & 0.001000 \\
\hdashline Std. Dev. & 0.265355 & 1.255639 & 0.961100 \\
Sum & 101.3990 & 168.5030 & 149.7030 \\
\hdashline Observations & 198 & 198 & 198 \\
\hline
\end{tabular}

\subsection{Managerial ownership (MO)}

The results show that $\mathrm{SD}$ value is lower than its average, while a maximum value is above average. It shows that proportion of managerial ownership indicates good results. As a whole, stock ownership of manufacturer in Indonesia on the hand of management is relatively high, so every management decision would involve the board of commissioners.

\subsection{Leverage (LEV)}

The results show that SD is higher than its average, while minimal debt value is larger than its average value, and the highest value of the debt is higher than its average. It indicates that corporations in Indonesia generally tend to use loans for investment.

\subsection{Dividend policy (DEV)}

The results show that the average value of dividend payments is 0.756 . Companies that pay the largest dividend are 5.525, while companies that pay the lowest dividend are 0.001 . The results show that the range between the lowest dividend payment policy and the highest is very far, which indicates that the dividend payment policy between companies in the industry varies greatly depending on the interests and needs of the company.

\subsection{Granger causality analysis}

\subsubsection{Test to determine the best model}

The results above show that the optimum lag is 1 with indication that the most star signs $\left(^{*}\right)$ are on lag 1. On lag 1, AIC value is the lowest among other lags, that is, 3.511368. According to AIC criteria, the model is appropriate if AIC value is the lowest. From the results above, AIC value is the lowest on lag 1 , thus the model is in appropriate category.

\subsubsection{Granger causality test}

The research tests bidirectional effect of managerial ownership, leverage and dividend policy (hypotheses tests on $\mathrm{H} 1, \mathrm{H} 2$ and $\mathrm{H} 3$ ). The test is performed by applying Granger causality test at 5\% (0.05) and 10\% $(0.1 \%)$ significance level. The result of Engle-Granger causality test with lag 1 is presented in Table 3 .

Table 3. Granger causality test results

Source: Data processing

\begin{tabular}{c|c:c}
\hline \multicolumn{3}{c}{ Lag: 1 } \\
\hline Null hypothesis & F-statistic & Prob. \\
\hline LEV does not Granger cause MO & 0.20713 & 0.6496 \\
\hline MO does not Granger cause LEV & 0.09916 & 0.7532 \\
\hdashline DPR does not Granger cause MO & 1.81716 & 0.0481 \\
\hline MO does not Granger cause DPR & 5.00354 & 0.0267 \\
\hline DPR does not Granger cause LEV & 0.00371 & 0.9515 \\
\hline LEV does not Granger cause DPR & 1.44535 & 0.0912 \\
\hline
\end{tabular}

From Table 3 with lag 1 at $(\alpha) 0.05$ and 0.1 significance levels, the nature of effects between variables is as follows:

Table 2. Testing model with AIC

\begin{tabular}{|c|c|c|c|c|c|c|}
\hline Lag & LagL & LR & FPE & AIC & $\mathrm{SC}$ & $\mathrm{HQ}$ \\
\hline 0 & -55.18937 & $\mathrm{NA}^{*}$ & 0.006826 & 3.526628 & $3.662674 *$ & $3.572404 *$ \\
\hline 1 & -45.93757 & 16.26074 & $0.006747^{*}$ & $3.511368^{*}$ & 4.055552 & 3.694469 \\
\hline 2 & -42.72845 & 5.056800 & 0.009738 & 3.862330 & 4.814653 & 4.182758 \\
\hline 3 & -36.01001 & 9.365087 & 0.011631 & 4.000607 & 5.361068 & 4.458361 \\
\hline 4 & -24.13213 & 14.39744 & 0.010542 & 3.826189 & 5.594789 & 4.421270 \\
\hline 5 & -10.00963 & 14.55046 & 0.008816 & 3.515735 & 5.692473 & 4.248141 \\
\hline
\end{tabular}


1. MO variable does not significantly affect LEV where probability value is higher than significance value of $(\alpha) 0.05 \quad(0.6496>0.05)$. $\mathrm{LEV}$ variable does not significantly affect $\mathrm{MO}$ where probability value is higher than alpha $(0.7532>0.05)$. Thus, it can be concluded that there is no causal relationship between the two variables, $\mathrm{H} 1$ is not supported.

2. MO variable significantly affects DPR where probability value is lower than significance value of $(\alpha) \quad(0.0481<0.05)$. DPR also significantly affects $\mathrm{MO}$ where probability is lower than alpha $(0.0267<0.05)$. Thus, it can be concluded that there is bidirectional causality between two variables, and $\mathrm{H} 2$ is supported.

3. LEV variable significantly affects DPR where probability value is lower than significance level of $(\alpha) 0.1(0.0912<0.10)$. However, DPR variable does not significantly affect LEV where probability value is higher than significance value of $(\alpha) 0.05(0.9515>0.05)$, and LEV variable does not significantly affect DPR where probability value is higher than significance level of $(\alpha) 5 \%(0.0912>0.05)$. Thus, it can be concluded that there is only unidirectional causality at $10 \%$ significance level, and no causality between the two variables at $5 \%$ significance level and $\mathrm{H} 3$ is not supported.

\section{DISCUSSION}

\subsection{There is no causality effect of managerial ownership on leverage}

According to pecking order theory, managers would make hierarchical choices in deciding the financing sources, that is, retained earning, debt and stock issuance. In terms of research results, higher managerial ownership does not have an effect on decreased corporate capital from retained earning and otherwise. If capital is from retained earning, then control over the capital would get weaker because of the absence of costs and risk. There is no bidirectional causality between managerial ownership and leverage (debt), mainly due to the belief of managerial ownership that the fi- nancing source would be allocated to prospective investment. By this way, the increased managerial ownership does not have an effect on corporate financing sources, both internal and external.

Based on trade-off theory, managers who have stocks in corporation with high debt ratio do not bear higher risk than corporate owners do, and their stock ownership does not mitigate agency conflict. In Indonesia, corporations are commonly dominated by institutional ownership. By this way, managerial decisions are strongly controlled. It partially explains relative absence of serious agency problem. The usage of debt as financing source would increase monitoring from bondholders and makes shareholders more reissued, as investment financing does not involve their money and decreases risk from shareholders accordingly. These results do not support Jensen et al. (1976). But they are in line with some works such as Friend and Lang (1988), Jensen et al. (1992), Chen and Steiner (1999), Tandelilin and Wilberforce (2002), Miguel and Brito (2011), and Vo and Nguyen (2014) confirming the absence of bidirectional causality/ substitution between managerial ownership and leverage.

\subsection{There is a bidirectional causality of managerial ownership on dividend policy}

For understanding dividend, this research applies bird in the hand theory Gordon (1959). assumes that investor values more one bird on hand than one thousand birds in the sky. Corporation with higher managerial ownership tends to increase internal fund to finance investment, with the effect of lower dividend payment. Jensen (1986) provides evidence that managers are reluctant to pay dividend, because they would like to make use of profit for corporation growth or their self-interest. Chen and Steiner (1999) argue that bidirectional causality between managerial ownership and dividend solves agency problem. Hence, managerial ownership and dividend can be considered as mechanism that can deal with agency cost. It would be more effective if the two variables affect each other simustaneously to resolve the same problem. Lower dividend is related to managerial ownership program, while higher dividend is related to the non-ex- 
istence of managerial ownership. Tandelilin and Wilberforce (2002) find the operation of bidirectional causality between dividend payment and managerial ownership. The possible relationship between dividend payment and managerial ownership is mutually complementary in oversight mechanism of agency problem.

The research results lend support from Vo and Nguyen (2014), Rozeff (1982), Jensen et al. (1992), Espen Eckbo and Verma (1994) who state that there is a negative bidirectional causality between managerial ownership and dividend payment. Jensen et al. (1976) state that managerial ownership can deal with interest conflict in corporation within dividend payoutratiocontext.

\subsection{There is unidirectional causality at $10 \%$ significance level and there is no bidirectional causality between leverage and dividend policy at $5 \%$ significance level}

The research results support Jensen et al. (1992), Chen and Steiner (1999) stating that there is unidirectional causality between debt and dividend payment policy. Leverage has a significant and negative effect on dividend policy. Incorporation wants to add capital by means of pecking order theory, it would take it from retained earning (internal fund), which would make dividend payment to shareholders become smaller. A corporation in Indonesia applies dividend signalling theory or agency theory of dividend for dividend policy. With debt as financing source, go-public corporations in
Indonesia want to attract investor's attention to buy and to impress society that they have recovered from crises, while profit obtained is used to pay dividend to investors, with bird in hand theory, where investors are viewed to favor the dividend payment than capital gain.

Leverage can decrease dividend payout ratio (DPR) when managerial ownership in a corporation is high. It is because high managerial ownership in stock should lead to managerial responsibility on daily operation and higher prudence in allocating corporation's debt. It would make dividend payment to shareholders become smaller, as managers think that using money from profit is more efficient than that from debt with higher risks. Hence, high managerial ownership would lower down dividend payment.

Dividend payment policy does not have an effect on debt rate, as investors are more concerned with performanceand management in corporation financing sources in order to obtain additional value from dividend payment policy. In other words, it can be said that any increase in dividend policy does not have an effect on debt policy. To increase investors' trust, corporations make high dividend payment from its net profit. This dividend payment policy does not significantly affect debt. According totrade-off theory, corporation favors external financing such as debt to finance its projects/investments (Myers \& Majluf, 1984). The research results also differ from Tandelilin and Wilberforce (2002) who find bidirectional causality between dividend payment and debt.

\section{CONCLUSION}

There is a bidirectional relationship between managerial ownership and dividend payout ratio. It indicates that managerial implication and dividend can be considered as mechanism to mitigate agency cost. More effective result would be obtained if the two variables affect each other to resolve the same problem in a corporation.

Leverage does not affect dividend payout ratio, while dividend payout ratio affects leverage, which signals the existence of unidirectional causality. In terms of pecking order theory, corporation favors internal financing, that is, retained earning to increase investors' trust, while in terms of trade-off theory, financing from debt can attract investors' attention to buy stocks and impress society that corporation has settled down by paying high dividend and financing investment from debt financing. 


\section{FUTURE RESEARCH}

Future research could develop the model by including another variable such as public and institutional ownership structures, taking into account other industrial sectors or applying imbalance panel data in expectation of having a better model.

Other aspects could serve as strengthening or weakening the effects of variables. Cultural or social aspects, for instance, could moderate the relationship between the variables concerning the agency problem, and its exploration could enrich management literature.

\section{REFERENCES}

1. Alderson, M. J., Bansal, N., \& Betker, B. L. (2013). Secured debt and managerial incentives. Review of Quantitative Finance and Accounting, 43(3), 423-440. https://doi.org/10.1007/s11156013-0380-x

2. Al-Malkawi, H. N. (2007). Determinant of Corporate Dividend Policy in Jordan: An Applocation of Tobit Model. Journal of Economic and Administrative Sciences, 23(2), 44-70. https://doi. org/10.1108/10264116200700007

3. Al-Taleb, G. (2012). Measurement of Impact Agency Costs Level of Firms on Dividend and Leverage Policy: An Empirical Study. Journal Of Contemporary Research In Business, 3(10) 234-243. Retrieved from https://www.researchgate.net/ publication/292792226_Measurement_of_Impact_Agency_ Costs_Level_of_Firms_on_Dividend_and_Leverage_Policy_An_ Empirical_Study_Interdisciplinary

4. Anil, K., \& Kapoor, S. (2008). Determinants of Dividend Payout Ratios-A Study of Indian Information Technology Sector. International Research Journal of Finance and Economics, 15. Retrieved from https://www. researchgate.net/publication/292102741_Determinants_of_ dividend_payout_ratio_A_study_ of_Indian_IT_sector

5. Bathala, C. T., Moon, K. P., \& Rao, R. P. (1994). Managerial Ownership, Debt Policy, and the Impact of Institutional Holdings: An Agency Perspective. Financial Management, 23(3), 38-50. https:// doi.org/10.2307/3665620
6. Brennan, M. J. (1970). Taxes, Market Valuation And Corporate Financial Policy. National Tax Journal, 23(4), 417-427. Retrieved from https://www.jstor.org/ stable/41792223?seq=1\#page scan_tab_contents

7. Chen, C. R., \& Steiner, T. L. (1999). Managerial ownership and agency conflicts: A nonlinear simultaneous equation analysis of managerial ownership, risk taking, debt policy, and dividend policy. Financial Review, 34(1), 119-136. https:// doi.org/10.1111/j.1540-6288.1999. tb00448.x

8. Chow, C. W., \& Rice, S. J. (1982). Qualified Audit Opinions and Auditor Switching. The Accounting Review, 57(2), 326-335. Retrieved from https://www.jstor.org/ stable/247018?seq=1\#page_scan_ tab_contents

9. Collins, D. W., \& Kothari, S. P. (1989). An analysis of intertemporal and cross-sectional determinants of earnings response coefficients. Journal of Accounting and Economics, 11(2-3), 143-181. https://doi.org/10.1016/01654101(89)90004-9

10. Crutchley, C. E., Jensen, M. R. H., Jahera, J. S., \& Raymond, J. E. (1999). Agency problems and the simultaneity of financial decision making: The role of institutional ownership. International Review of Financial Analysis, 8(2), 177-197. https://doi.org/10.1016/S10575219(99)00011-3

11. Djebali, R., Belanes, A., \& Omri, A. (2011). Simultaneous Determination of Firm Leverage and Private Benefits of Control in French Firms. International Journal of Economics and Finance, 4(1). https://doi.org/10.5539/ijef. v4n1p177

12. Eisenhardt, K. M. (1989). Agency Theory: An Assessment and Review. Academy of Management Review, 14(1), 57-74. https://doi. org/10.5465/AMR.1989.4279003

13. Espen Eckbo, B., \& Verma, S. (1994). Managerial shareownership, voting power, and cash dividend policy. Journal of Corporate Finance, 1(1), 33-62. https://doi.org/10.1016/09291199(94)90009-4

14. Frankfurter, G. M., Wood, B. G., \& Wansley, J. (2003). Dividend Policy: Theory and Practice (236 p.). Elsevier Inc. https://doi. org/10.1016/B978-0-12-266051-1. X5000-X

15. Friend, I., \& Lang, L. H. P. (1988). An Empirical Test of the Impact of Managerial Selfinterest on Corporate Capital Structure. The Journal of Finance, 43(2), 271-281. https://doi. org/10.1111/j.1540-6261.1988. tb03938.x

16. Gordon, M. J. (1959). Dividends, Earnings, and Stock Prices. The Review of Economics and Statistics, 41(2), 99-105. https://doi. org/10.2307/1927792

17. Gordon, M. J., \& Gordont, M. J. (1963). Optimal Investment and Financing Policy. The Journal of Finance, 18(2), 264-272. https:// doi.org/10.2307/2977907

18. Hanafi, Mahmud M. (2004). ManajemenKeuangan. Yogyakarta: BPFE. 
19. Jensen, G. R., Solberg, D. P., \& Zorn, T. S. (1992). Simultaneous Determination of Insider Ownership, Debt, and Dividend Policies. The Journal of Financial and Quantitative Analysis, 27(2), 247. https://doi. org/10.2307/2331370

20. Jensen, M. C. (1986). Agency Costs of Free Cash Flow, Corporate Finance, and Takeovers. American Economic Review, 76(2), 323-329. https://doi.org/10.2139/ ssrn. 99580

21. Jensen, M. C., \& Ruback, R. S. (1983). The market for corporate control: The scientific evidence. Journal of Financial Economics, 11(1-4), 5-50. https://doi.org/10.1016/0304405X(83)90004-1

22. Jensen, C., \& Meckling, H. (1976). Theory of the firm: Managerial behavior, agency costs and ownership structure. Journal of Financial Economics, 3(4), 305360. https://doi.org/10.1016/0304405X(76)90026-X

23. Kieso, D. E., Weygandt, J. J., \& Warfield, T. D. (2015) Intermediate Accounting: IFRS Edition, Volume 1. Jurnal Akuntansi \& Auditing Indonesia, (Bissessar 2010), 800. https://doi. org/10.20885/jaai.vol19.iss1.art3

24. Kraus, A., \& Litzenberger, R. H. (1973). A state-preference model of optimal financial leverage. The Journal of Finance, 28(4), 911-922. https://doi. $\operatorname{org} / 10.1111 / \mathrm{j} \cdot 1540-6261.1973$. tb01415.x

25. Liao, W., \& Chien, S. (2013). The effect of profit incentive of ICT industry on the relationship between ownership and corporate performance. African Journal of Business Management, 26, 25222532. Retrieved from https://academicjournals.org/journal/AJBM/ article-abstract/7671DF637998

26. McCraw, T. K. (1990). The Modern Corporation and Private Property. Reviews in American History, 18(4), 578-596. https://doi. org/10.2307/2703058

27. Miguel, P. L. S., \& Brito, L. A. L. (2011). Supply chain management measurement and its influence on operational performance. Journal of Operations and Supply
Chain Management, 4(2), 56-70. https://doi.org/10.12660/joscmv4n2p56-70

28. Miller, M. H., \& Modigliani, F. (1961). Dividend Policy, Growth, and the Valuation of Shares. The Journal of Business, 34(4), 411-433. https://doi.org/10.1086/294442

29. Modigliani, F., \& Miller, M. H. (1958). The cost of capital: Corporation finance and the theory of Investment. American Economic Review, 48(3), 261.

30. Modigliani, F., \& Miller, M. H. M. (1963). Corporate Income Taxes and the Cost of Capital: A Correction. American Economic Review, 53(3), 433-443.

31. Moeljadi (2006). Manajemen Keuangan (Pendekatan Kuantitatif dan Kualitatif). Bayumedia Publishing Malang, Edisi Pertama.

32. Mursalim (2009). Economic Value Added dan Market Value Added Dampaknya terhadap Nilai Perusahaan. Jurusan Manajemen Fakultas Ekonomi Universitas Hasanuddin Makassar.

33. Myers, S. C., \& Majluf, N. S. (1984). Corporate financing and investment decisions when firms have information that investors do not have. Journal of Financial Economics, 13(2), 187-221. https://doi.org/10.1016/0304405X(84)90023-0

34. Nyonna, D. Y. (2012, October). Simultaneous Determination of Insider Ownership and Leverage: The Case of Small Businesses. Economicse Business Journal: Inquiries \& Perspectives, 9, 9-20.

35. Rozeff, M. S. (1982). Growth, Beta and Agency Costs As Determinants of Dividend Payout Ratios. Journal of Financial Research, 5(3), 249-259. https:// doi.org/10.1111/j.1475-6803.1982. tb00299.x

36. Sundaramurthy (2005). Corporate Governance and Real Earnings Management. Academy of Accounting and Financial Studies Journal, 12(1).

37. Tandelilin, E., \& Wilberforce, T. (2002). Can Debt and Dividend Policies Substitute Insider
Ownership in Controling Equity Agency Conflict? Gadjah Mada International Journal of Business, 1(1), 31-43. Retrieved from https:// www.researchgate.net/publication/277136534_CAN_DEBT_ AND_DIVIDEND_POLICIES SUBSTITUTE_INSIDER_OWNERSHIP_IN_CONTROLLING_ EQUITY_AGENCY_CONFLICT

38. Thanatawee, Y. (2013). Ownership Structure and Dividend Policy: Evidence from Thailand. International Journal of Economics and Finance, 5(1), 121-132. https:// doi.org/10.5539/ijef.v5n1p121

39. Tsay, R. S., Lin, Y. M., \& Wang, H. W. (2008). Residual income, value-relevant information and equity valuation: A simultaneous equations approach. Review of Quantitative Finance and Accounting, 31(4), 331-358. https:// doi.org/10.1007/s11156-0070081-4

40. Vo, D. H., \& Nguyen, V. T. (2014). Managerial Ownership, Leverage and Dividend Policies: Empirical Evidence from Vietnam's Listed Firms. International Journal of Economics and Finance, 6(5), 274285. https://doi.org/10.5539/ijef. v6n5p274

41. Weston, J. F., \& Brigham (1994). Dasar ManagemenKeuangan. Jakarta: Erlangga. 